\title{
STUDIES ON THE METABOLISM OF PLASMA PROTEINS IN THE NEPHROTIC SYNDROME. II. THE LIPOPROTEINS ${ }^{\mathbf{1 , 2}}$
}

\author{
By DAVID GITLIN, DAVID G. CORNWELL, ${ }^{3}$ DORIS NAKASATO, J. L. ONCLEY, \\ WALTER L. HUGHES, JR., AND CHARLES A. JANEWAY \\ (From the Departments of Pediatrics and Biochemistry, Harvard Medical School, the Children's \\ Medical Center, Boston, Mass., and the Medical Department, Brookhaven National \\ Laboratory, Upton, N. Y.)
}

(Submitted for publication June 3, 1957; accepted October 17, 1957)

It is now generally agreed that essentially all of the cholesterol and phospholipid in human plasma is associated with polypeptides in lipidpeptide complexes classified as lipoproteins (1). It is also generally accepted, with some reservations (2), that these lipoproteins can be divided electrophoretically into two major groups (1), $\alpha$-lipoproteins and $\beta$-lipoproteins, which differ from each other with regard to solubility, molecular weight, and content of protein, cholesterol, phospholipid, and neutral fat. The lipoproteins can be differentiated still further according to the density of the individual molecules $(3-6)$, lipoproteins of different densities differing in their relative content of protein and lipid. The relationship of chylomicra to lipoproteins is not yet clear and, although less than 1 per cent of the weight of chylomicra is peptide, chylomicra are frequently, but not universally, considered as lipoproteins.

The lipids in lipoproteins appear to be exchangeable in vivo and in vitro: cholesterol and phospholipids on $\alpha$-lipoproteins apparently can exchange with those of $\beta$-lipoproteins and vice versa $(7,8)$. The interrelationships of the peptide moieties of lipoproteins, however, are not known. It has been suggested (9) that the peptide moiety of $\alpha$-lipoprotein goes through a continuous cycle, acquiring lipids to form chylomicra and possibly low density $\beta$-lipoproteins; chylomicra and low density $\beta$-lipoproteins then release glycerol, fatty

1 Supported by grants from the National Institutes of Health, United States Public Health Service (A-251), from the United States Atomic Energy Commission, and from the Muscular Dystrophy Associations of America.

2 Read in part before the Federation of American Societies for Experimental Biology, Atlantic City, N. J., April, 1956.

${ }^{3}$ Lilly Research Laboratories Fellow in the Medical Sciences, National Academy of Science, National Research Council. acids, and possibly other lipids through the action of lipoprotein lipase to reform $\alpha$-lipoprotein.

In the present investigation, attention was directed to the metabolism of human serum lipoproteins in an effort to determine the factors responsible for hyperlipemia and hypercholesterolemia in children with the nephrotic syndrome. For this purpose, specific lipoproteins were isolated by ultracentrifugation from normal sera and from sera of children with this disease. The peptide moieties of the isolated lipoproteins were labeled using $\mathrm{I}^{131}$ and the turnover and interconversion of these proteins in normal individuals and in children with the nephrotic syndrome were studied.

\section{METHODS}

Patients. Six children with the nephrotic syndrome were selected for study (Table I). Three of these had been studied a year previously with regard to their metabolism of albumin and $\gamma$-globulin (10); in the interim, one child, K. S., had almost completely recovered from the disease, but the clinical status of the other two children, E. T. and D. W., had remained essentially unchanged. As in the earlier study, the six patients represented three recognizable stages of the disease: Group I, one child in the latent phase of the nephrotic syndrome who had almost complete remission and no longer had hypoproteinemia, ascites, edema, or hyperlipemia, but still had residual proteinuria; Group II, one child with only minimal intermittent edema and without ascites but with proteinuria, hypoproteinemia and hyperlipemia; Group III, four children with full-blown disease manifesting proteinuria, hypoproteinemia, anasarca, ascites, and hyperlipemia. Thus, all the children of Groups II and III had hyperlipemia and hypercholesterolemia.

Normal subjects. Eight men and one woman, all between the ages of 21 and 29 years (Table I), were selected as subjects to study the normal metabolism of human plasma lipoproteins. These individuals had normal serum cholesterol levels and showed no evidence of cardiac, renal, or hepatic disease. No attempt was made to regulate their diets during the course of this study 
and there was no restriction of activity. It will be noted that this group was considerably older than the nephrotic children studied. The behavior of the labeled lipoproteins in these adults, however, was similar to that observed in the child, K. S., who had recovered from the nephrotic syndrome.

Isolation of lipoproteins used for iodination. The lipoproteins used in this study were obtained from the serum of individual healthy adults and from the serum of one child, D. O., in Group III. Three major groups of lipoproteins were isolated and iodinated: 1) low density $\beta$-lipoproteins or lipoproteins of density less than $1.000 \mathrm{Gm}$. per ml.; 2) higher density $\beta$-lipoproteins or those having an average density of $1.038 \mathrm{Gm}$. per $\mathrm{ml}$.; and 3) $\alpha$-lipoproteins of density greater than $1.125 \mathrm{Gm}$. per $\mathrm{ml}$.

Separation of the $\beta$-lipoproteins from normal serum was accomplished by precipitation with dextran sulfate (6). Subsequent dissociation of the $\beta$-lipoprotein-dextran sulfate complex was performed by ultracentrifugation (Spinco, Model L, Rotor No. 40) in a sodium chloride density gradient tube at 105,000 times $G$ for 18 hours. In this method, the low density $\beta$-lipoproteins floated to the top of the gradient tube and the higher density $\beta$-lipoproteins formed a narrow band in the middle portion of the tube; other proteins and the dextran sulfate sedimented to the bottom of the tube. The lipoprotein layers were removed from the gradient tube with the aid of a tube-cutter (11) and aliquots analyzed with an airdriven ultracentrifuge in a sodium chloride solution of density $1.063 \mathrm{Gm}$. per ml. at $25^{\circ} \mathrm{C}$. The Svedberg unit, as modified by de Lalla and Gofman (12), was used to define flotation rates and is signified by the conventional symbol, $S_{\mathbf{f}}$. The $\beta$-lipoprotein patterns were analyzed with the aid of the distribution function developed by Williams, Saunders, and Cicirelli (13) to describe heterogeneous high polymer systems. The analyses revealed that the low density $\beta$-lipoproteins prepared by dextran sulfate precipitation contained lipoproteins in the $S_{f} 10$ to 100 range with a preponderance of lipoproteins in the $S_{t} 20$ to 60 range. The higher density $\beta$-lipoproteins were found to be in the $S_{f} 3$ to 9 range. Assay for dextran sulfate, based on the effect of dextran sulfate on the prothrombin time of a one-step clotting system, revealed less than $0.5 \mu \mathrm{g}$. of dextran sulfate per $\mathrm{ml}$. of lipoprotein fraction (6).

Low density $\beta$-lipoproteins were prepared from the serum of Patient D. O. in Group III by direct ultracentrifugal flotation of the serum in a sodium chloride density gradient tube. To prevent contamination of the low density lipoproteins with chylomicra, the serum was first centrifuged at 25,000 times $G$ for 30 minutes; the chylomicra floated to the top of the tube and were separated from the subnatant serum. Analysis of the lowdensity lipoproteins showed an $S_{\mathbb{f}}$ range of 10 to 200 .

The preparation of $\alpha$-lipoproteins used in this study was kindly supplied by Dr. Ella M. Russ, Cornell Medical School. This preparation was obtained from the plasma of a single donor by low temperature, ethanolwater fractionation (14) and subsequently floated at 100,000 times $G$ in a solution of potassium bromide (15).
The solution of $\alpha$-lipoproteins was dialyzed against $2 \mathrm{M}$ $\mathrm{NaCl}$ to remove the $\mathrm{KBr}$ before the iodination procedure.

Radioiodinated lipoproteins. The following lipoprotein preparations were iodinated : 1) low density $\beta$-lipoproteins from normal sera, 2) high density $\beta$-lipoproteins from normal sera, 3) low density $\beta$-lipoproteins from nephrotic serum, and 4) $\alpha$-lipoproteins from normal serum. $I^{131}$ was obtained as carrier-free $\mathrm{NaI}$ in a sodium bisulfite solution and to this was added appropriate amounts of a solution of $0.94 \times 10^{-3} \mathrm{M} \mathrm{I}_{2}$ in $1.33 \times 10^{-8} \mathrm{M} \mathrm{KI}$ (16). The iodide and bisufite were oxidized with nitrous acid, which was subsequently neutralized with sodium hydroxide (17). The mixture was then added to a given lipoprotein solution in $0.2 \mathrm{M} \mathrm{NaHCO}-\mathrm{Na}_{2} \mathrm{CO}_{3}$ buffer at $\mathrm{pH} 9.5$. The $\beta$-lipoproteins were assumed to have a molecula weight of about $2,000,000$ and the $\alpha$-lipoproteins were assumed to have a molecular weight of about 200,000 (1). The iodinated lipoproteins were dialyzed for 24 hours against several changes of $0.15 \mathrm{M} \mathrm{NaCl}$ containing $0.05 \mathrm{Gm}$. per cent of the disodium salt of ethylenediaminetetraacetic acid (EDTA). Immediately after dialysis, sufficient amounts of purified human serum albumin were added to the iodinated lipoproteins to give a final albumin concentration of about $1 \mathrm{Gm}$. per cent. The preparations were than sterilized by pressure filtration through a sintered glass filter.

Human serum lipoproteins are relatively unstable at room temperatures and are readily oxidized when in the purified state. Consequently, certain precautions were considered essential: 1) all solutions and sera were kept between $1^{\circ} \mathrm{C}$. and $4^{\circ} \mathrm{C}$. at all times; 2) iodination of the lipoprotein fraction was performed within 24 to 48 hours after obtaining blood from the donor; 3 ) the radioiodinated lipoproteins were given to the recipients within 24 to 48 hours after iodination; 4) EDTA, to inhibit oxidation (18), was present in the lipoprotein preparations at all times after iodination and in several instances before iodination as well; and 5) human serum albumin was added after dialysis and before sterilization to inhibit oxidation and radiation effects (19).

Precipitation of the radioiodinated lipoproteins with an equal volume of 20 per cent trichloracetic acid, in the presence of unlabeled carrier, indicated that less than 2 per cent of the total radioactivity of each preparation was free or loosely bound to the protein. Extraction of the trichloracetic acid precipitates of the iodolipoproteins with organic solvents such as petroleum ether, diethyl ether, ethyl alcohol, and acetone, either singly or in combinations, failed to remove more than 0.5 per cent of the total radioactivity of the precipitates. Denaturation of the iodolipoproteins in the presence of carrier protein by heat and subsequent extraction with organic solvents also failed to remove significant amounts of radioactivity. It appeared that essentially all of the radioactivity in the iodolipoproteins was associated with the peptide moieties of the lipoproteins. It was calculated that the iodinated $\alpha$-lipoproteins had an average of two atoms of iodine per molecule, the high density $\beta$-lipoproteins about one atom of iodine per molecule and the low density $\beta$-lipoproteins an average of about 0.8 atom of iodine per molecule. 


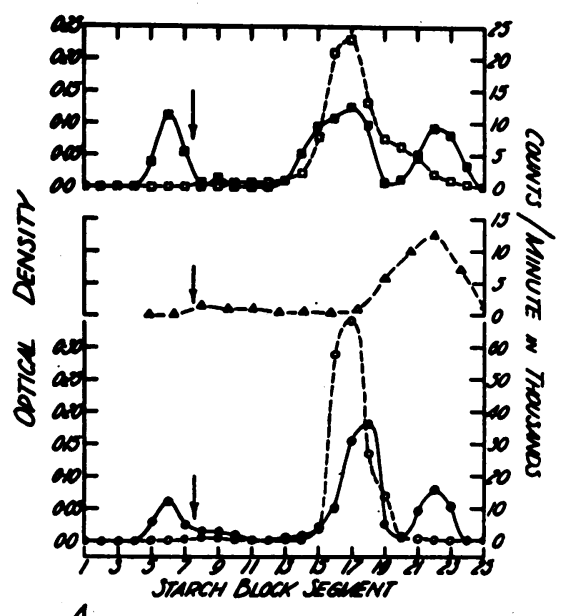

A.

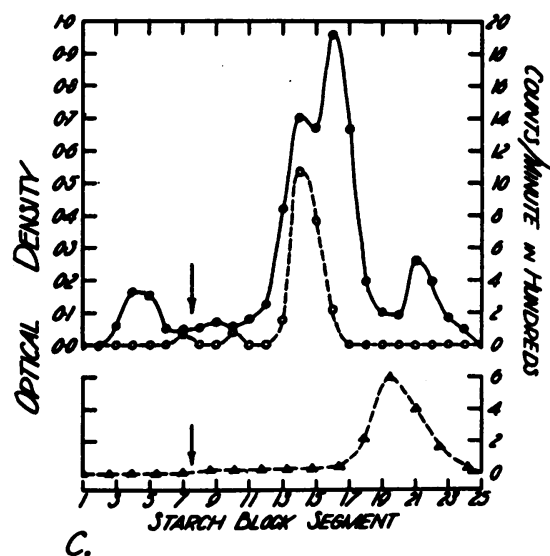

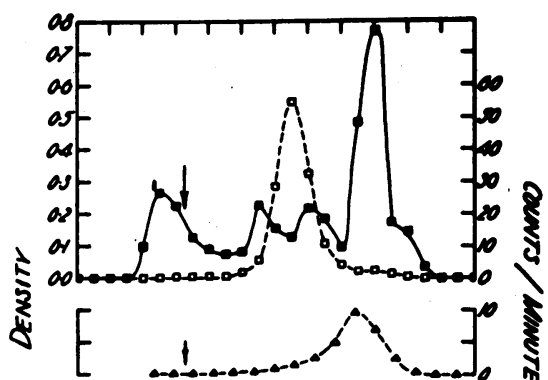

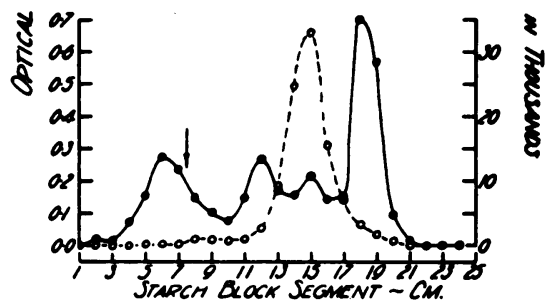

D.

Fig. 1. Starch Electrophoresis of $S_{\mathfrak{f}} 3$ to 9 Lipoproteins (SQuares), Low Density Lipoproteins (Circles) and $\alpha$-Lipoproteins (Triangles)

Dashed lines with open symbols represent radioactivity and solid lines with solid symbols represent optical density. Arrows indicate the origin. Starch cut into $1 \mathrm{~cm}$. segments. A. Iodinated lipoproteins in a mixture of unlabeled $S_{f} 3$ to 9 lipoprotein, $\gamma$-globulin, and albumin. B. Iodinated lipoproteins in plasma from normal individuals after 24 hours in vivo. C. Iodinated lipoproteins in plasma from nephrotic children after 24 hours in vivo.

There was some evidence that, as the density of the $\beta$-lipoproteins decreased, the amount of iodine bound per mol of protein under identical conditions decreased. It was assumed in this study, however, that the degree of labeling within a given lipoprotein fraction was uniform.

When added separately to unlabeled sera or other lipoprotein fractions in vitro, 90 per cent or more of the radioactivity of the iodinated lipoproteins was recoverable with the analogous ultracentrifugal fractions.

Zonal electrophoresis in starch (20) was used to study the relative mobility of the native lipoproteins and the radioiodinated derivatives. The starch blocks measured 4 by $30 \mathrm{~cm}$. and were enclosed in waxed paper ; electrophoresis was performed in barbiturate-citrate buffer, $\mathrm{pH}$ $8.6, \Gamma / 2$ equals 0.1 , at 15 volts per $\mathrm{cm}$. for 18 hours at $4^{\circ} \mathrm{C}$. The starch was then cut into segments and the proteins eluted with $0.15 \mathrm{M} \mathrm{NaCl}$. The optical densities of the eluates were measured in a Beckman spectrophotometer at a wave length of $280 \mathrm{~m} \mu$ : the eluates were also assayed for radioactivity. Electrophoretic patterns obtained for the three classes of lipoproteins studied are shown in Figure 1. The mobility of each specific iodolipoprotein was the same when examined either in a mixture of proteins prepared in vitro (Figure $1 \mathrm{~A}$ ) or in serum obtained after their intravenous injection (Figure $1, B$ and $C$ ). It was found that the radioactivity associated with lipoproteins of $S_{t} 3$ to 9 or $S_{t} 10$ to 200 did not shift to the more rapidly migrating $\alpha$-lipoproteins or vice versa, at any time in vitro or in vivo. The migration of the $S_{t} 3$ to 9 lipoproteins was like that of the low 
density lipoproteins and, in this system, migrated with a mobility between those of the $\alpha_{2}$ - and $\beta$-globulins.

Method of study. The iodolipoproteins were given intravenously. The specific activities of the proteins were such that no more than $1 \mathrm{mg}$. of any iodolipoprotein was injected per individual. The maximum radioactivity per injection was $0.4 \mu \mathrm{c}$. per $\mathrm{Kg}$. body weight. All persons studied were given 10 drops of Lugol's solution three times a day beginning about 24 hours prior to the injection of radioiodolipoprotein.

After the injection of radioiodolipoproteins, samples of venous blood were collected periodically and permitted to clot; the sera were separated and assayed for radioactivity. In this study, serum concentrations and plasma concentrations of lipoproteins were considered equivalent. In many instances, the lipoproteins were separated into the three density classes by ultracentrifugation. The volumes of the separate fractions were measured and the fractions assayed for radioactivity. The amount of cholesterol in each different density class was determined by the method of Abell, Levy, Brodie, and Kendall (21). All sera were centrifuged at 25,000 times $G$ for 30 minutes and separated from the layer of chylomicra at the top prior to ultracentrifugal fractionation. $S_{f}$ analysis of individual fractions of the $\beta$-lipoproteins was performed with an air-driven ultracentrifuge.

In several of the patients of Group III, it was possible to obtain large samples of edema and ascitic fluids at the end of the study; these were concentrated fifty- to one hundred-fold by negative pressure dialysis and this fractionated ultracentrifugally.
Urine collections were obtained in five of the normal subjects and in all of the nephrotic patients, the collection periods varying from several hours to several days. Aliquots were assayed for radioactivity.

Nonprotein radioiodide in serum, urine, edema, and ascitic fluid was estimated by adding an equal volume of 20 per cent trichloracetic acid to aliquots, allowing the mixtures to stand at $1^{\circ} \mathrm{C}$. for 2 to 24 hours, centrifuging and measuring the radioactivity of the supernatant.

Assay of radioactivity. All samples were counted in a well-type sodium iodide crystal scintillation counter which gave approximately $1 \times 10^{6}$ counts per minute per $\mu c$. of $I^{131}$. Problems of decay and geometry in counting samples were avoided by preparing standards from the radioiodolipoprotein solutions with the same syringe and needle used to inject the tracer dose.

Definition of terms. For convenience, the following definitions are offered:

The body pool of a given plasma protein is the total amount of that protein in the body which is available for exchange with additional or newly synthesized molecules of that specific protein.

The volume of distribution of a protein is taken as the volume that a protein would occupy if the body pool of the protein had a uniform concentration equal to the plasma concentration of that protein. This term has no anatomical implications and does not indicate the extent of distribution of the protein in the body.

The turnover half-time of a plasma protein is the amount of time required for half of the specific protein molecules present in the body pool at a given moment to

TABLE I

Distribution of serum cholesterol and peptide among the lipoproteins in the individuals studied

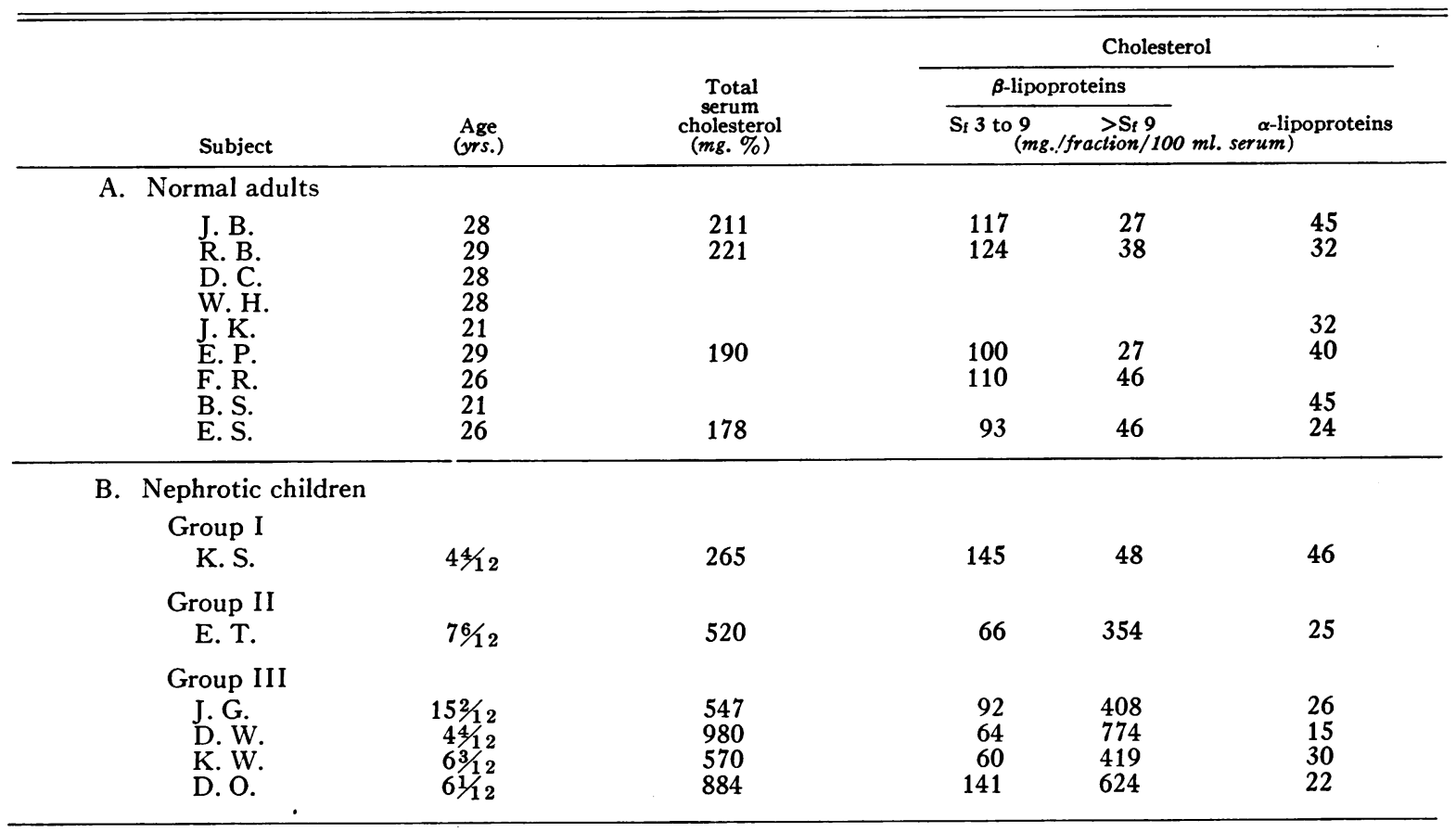



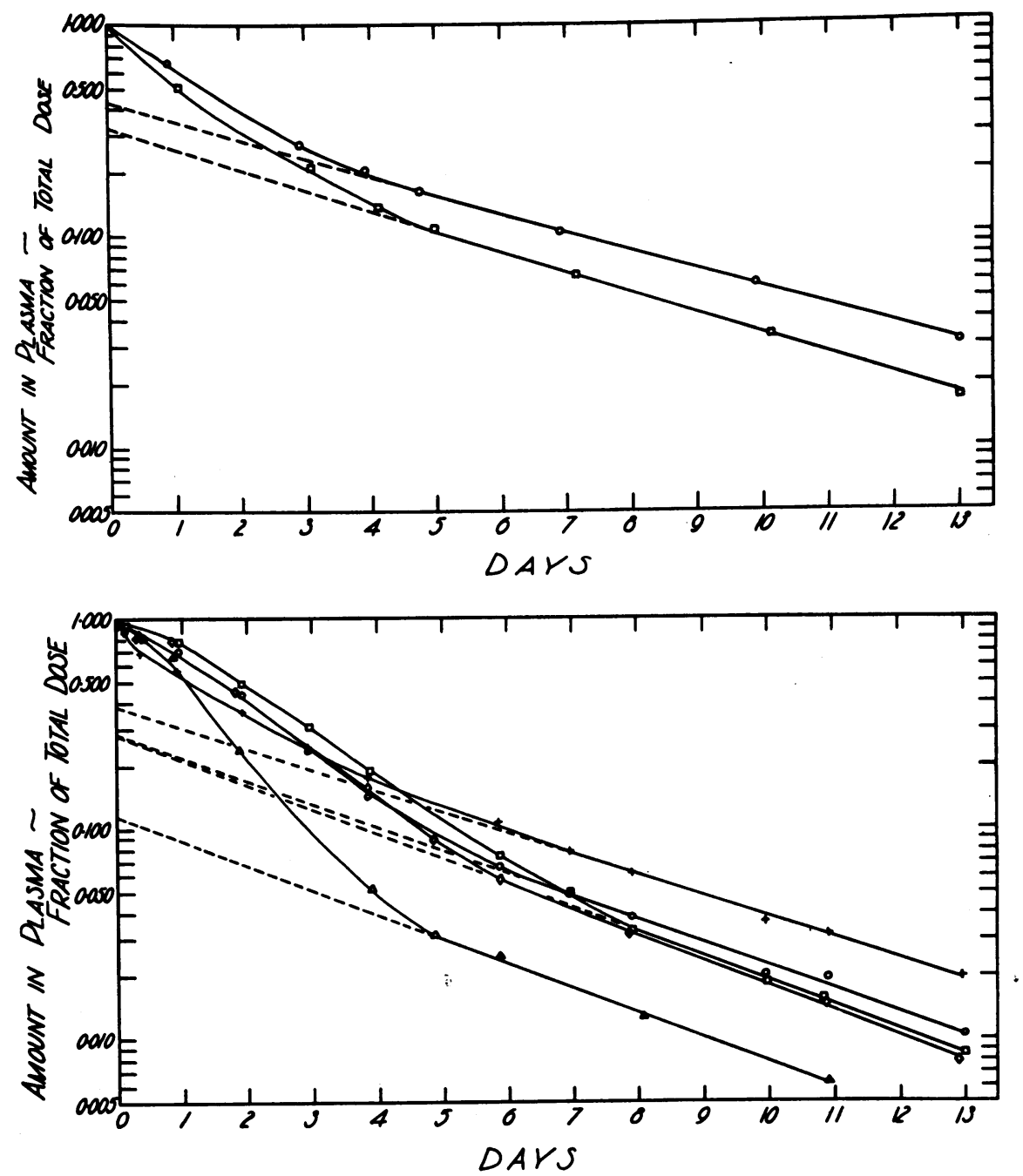

Fig. 2. The Disappearance of Iodinated $S_{f} 3$ to 9 Lipoproteins from the Circulation After Intravenous Injection

Upper chart, normal adults: $\square$ J. B. O E. S.

Lower chart, nephrotic children: + K. S. $\square$ E. T. $\diamond$ J. G. O D. W. $\Delta$ K.W.

be lost to the body through all channels of loss. The turnover half-time due to catabolism (or urinary loss) is the time required for half of the specific protein molecules present in the body pool at a given moment to be lost through catabolism (or urinary loss). The fractional rate of turnover, catabolism, or urinary loss is that fraction of the body pool of a given protein that is replaced, catabolized, or excreted, respectively, per unit time.

The values for lipoprotein turnover expressed in this paper are in terms of their peptide moieties, since the label is bound only to this portion of the lipoprotein molecule and the lipids may behave in an independent manner.

\section{RESULTS}

\section{Lipoprotein analyses}

The amount of cholesterol found in the different classes of lipoprotein present in the sera of the individuals studied are given in Table I. The values given are in terms of mg. of cholesterol per total lipoproteins of a given density class per 100 $\mathrm{ml}$. of serum. It should be noted that in all of the children with hypercholesterolemia reported here, the serum elevation of cholesterol was attributable to an increase in the amount of low density lipo- 
proteins; in these same children, the concentration of lipoprotein of $S_{f} 3$ to 9 was normal or decreased, as was the concentration of $\alpha$-lipoproteins.

\section{Studies with radioiodinated serum lipoproteins of class $S_{f} 3$ to 9}

The disappearance of radioiodinated normal $S_{f}$ 3 to 9 lipoproteins from the plasma of two normal adults and five children with the nephrotic syndrome is shown in Figure 2. Ultracentrifugal analysis of individual sera showed that 93 to 99 per cent of the iodinated $S_{t} 3$ to 9 lipoproteins retained in the plasma remained in the serum $S_{f} 3$ to 9 fraction throughout the period of study. The turnover half-times, as determined by simple graphic analysis of these curves, are indicated in Table II, A. It will be noted that the turnover half-times for this class of lipoproteins were only slightly less in the nephrotic children with hypercholesterolemia (Groups II and III) than in the normal subjects or in the child recovering from the nephrotic syndrome. When the curves of Figure 2 were corrected by the method of Berson, Yalow, Schreiber, and Post (22), the resulting turnover half-times were not significantly different from those obtained from the plasma disappearance curves alone. Examination of Figure 2 will reveal that the labeled lipoproteins disappeared from the plasma in an unusual fashion in all of the children with hypercholesterolemia; initially, the disappearance was gradual, then rapidly increased and finally became exponential. The reasons for the initial slow disappearance were not apparent from the data. Of the total injected dose of radioactivity, only 3 per cent or less appeared in the urine of the nephrotic children as labeled lipoprotein; in the normal individuals, none of the injected radioactivity was detected in the urine as labeled protein (Table II, A).

The volumes of distribution, as estimated by extrapolation of the single exponential phase of the plasma disappearance curves to zero time (Figure 2), seemed at first to be larger for these lipoproteins than has been the case for other plasma proteins studied in normal and nephrotic individuals (10). It has been shown, however, that such plasma disappearance curves cannot be

TABLE II

Turnover of $S_{f} 3$ to 9 lipoproteins and $\alpha$-lipoproteins

\begin{tabular}{|c|c|c|c|c|c|c|c|c|}
\hline \multirow[b]{3}{*}{ Individual } & \multirow[b]{3}{*}{$\begin{array}{c}\text { Plasma } \\
\text { volume } \\
(m l .)\end{array}$} & \multirow{3}{*}{$\begin{array}{c}\text { Estimated } \\
\text { cumulative } \\
\text { urinary } \\
\text { losses of } \\
\text { iodinated } \\
\text { protein* } \\
\mathrm{L}_{f^{*}}\end{array}$} & \multicolumn{3}{|c|}{ Approximate half-time of turnover } & \multirow{2}{*}{\multicolumn{3}{|c|}{ Fractional rate of turnover }} \\
\hline & & & \multirow{2}{*}{$\begin{array}{c}\text { From } \\
\text { plasma } \\
\text { disap- } \\
\text { pearance } \\
t_{t} \frac{1}{3} \\
(\text { days })\end{array}$} & \multirow[b]{2}{*}{$\begin{array}{c}\text { Urinary } \\
\text { loss } \\
\text { tot } \\
(\text { days })\end{array}$} & \multirow[b]{2}{*}{$\begin{array}{l}\text { Catab- } \\
\text { olism } \\
\text { tot }^{\frac{3}{3}} \\
(\text { days })\end{array}$} & & & \\
\hline & & & & & & $\begin{array}{c}\text { Total } \\
\lambda_{t} \\
\text { (per day) }\end{array}$ & $\begin{array}{c}\text { Urinary } \\
\text { loss } \\
\lambda_{0} \\
\text { (per day) }\end{array}$ & $\begin{array}{c}\text { Catab- } \\
\text { olism } \\
\lambda_{c} \\
\text { (per day) }\end{array}$ \\
\hline \multicolumn{9}{|c|}{ A. $S_{f} 3$ to 9 lipoproteins } \\
\hline $\begin{array}{c}\text { Normal } \\
\text { J. B. } \\
\text { E. S. }\end{array}$ & $\begin{array}{l}2,767 \\
2,948\end{array}$ & $\begin{array}{l}0.00 \\
0.00\end{array}$ & $\begin{array}{l}3.1 \\
3.4\end{array}$ & $\begin{array}{l}\infty \\
\infty\end{array}$ & $\begin{array}{l}3.1 \\
3.4\end{array}$ & $\begin{array}{l}0.224 \\
0.204\end{array}$ & $\begin{array}{l}0 \\
0\end{array}$ & $\begin{array}{l}0.224 \\
0.204\end{array}$ \\
\hline $\begin{array}{l}\text { Nephrotic } \\
\text { I-K. S. } \\
\text { II-E. } \begin{array}{l}\text { T. } \\
\text { III }\left\{\begin{array}{l}\text { J. G. } \\
\text { D. W. } \\
\text { K. W. }\end{array}\right.\end{array}\end{array}$ & $\begin{array}{r}966 \\
1,294 \\
1,071 \\
789 \\
625\end{array}$ & $\begin{array}{l}0.01 \\
0.01 \\
0.03 \\
0.01 \\
0.01\end{array}$ & $\begin{array}{l}3.0 \\
2.6 \\
2.5 \\
2.8 \\
2.5\end{array}$ & $\begin{array}{r}347 \\
231 \\
87 \\
347 \\
231\end{array}$ & $\begin{array}{l}3.0 \\
2.6 \\
2.6 \\
2.8 \\
2.5\end{array}$ & $\begin{array}{l}0.231 \\
0.267 \\
0.277 \\
0.248 \\
0.277\end{array}$ & $\begin{array}{l}0.002 \\
0.003 \\
0.008 \\
0.002 \\
0.003\end{array}$ & $\begin{array}{l}0.229 \\
0.264 \\
0.269 \\
0.246 \\
0.274\end{array}$ \\
\hline \multicolumn{9}{|l|}{ B. $\alpha$-lipoproteins } \\
\hline $\begin{array}{c}\text { Normal } \\
\text { J. K. } \\
\text { B. S. }\end{array}$ & $\begin{array}{l}3,238 \\
3,493\end{array}$ & $\begin{array}{l}0.00 \\
0.00\end{array}$ & $\begin{array}{l}4.8 \\
4.4\end{array}$ & $\begin{array}{l}\infty \\
\infty\end{array}$ & $\begin{array}{l}4.8 \\
4.4\end{array}$ & $\begin{array}{l}0.144 \\
0.158\end{array}$ & $\begin{array}{l}\mathbf{0} \\
\mathbf{0}\end{array}$ & $\begin{array}{l}0.144 \\
0.158\end{array}$ \\
\hline $\begin{array}{l}\text { Nephrotic } \\
\text { I-K. S. } \\
\text { II-E. T. } \\
\text { III-D. W. }\end{array}$ & $\begin{array}{r}995 \\
1,225 \\
804\end{array}$ & $\begin{array}{l}0.01 \\
0.19 \\
0.25\end{array}$ & $\begin{array}{l}3.7 \\
3.3 \\
2.3\end{array}$ & $\begin{array}{c}347 \\
17 \\
9.2\end{array}$ & $\begin{array}{l}3.7 \\
4.1 \\
3.1\end{array}$ & $\begin{array}{l}0.187 \\
0.210 \\
0.301\end{array}$ & $\begin{array}{l}0.002 \\
0.040 \\
0.075\end{array}$ & $\begin{array}{l}0.185 \\
0.170 \\
0.226\end{array}$ \\
\hline
\end{tabular}

* As fraction of total dose. 

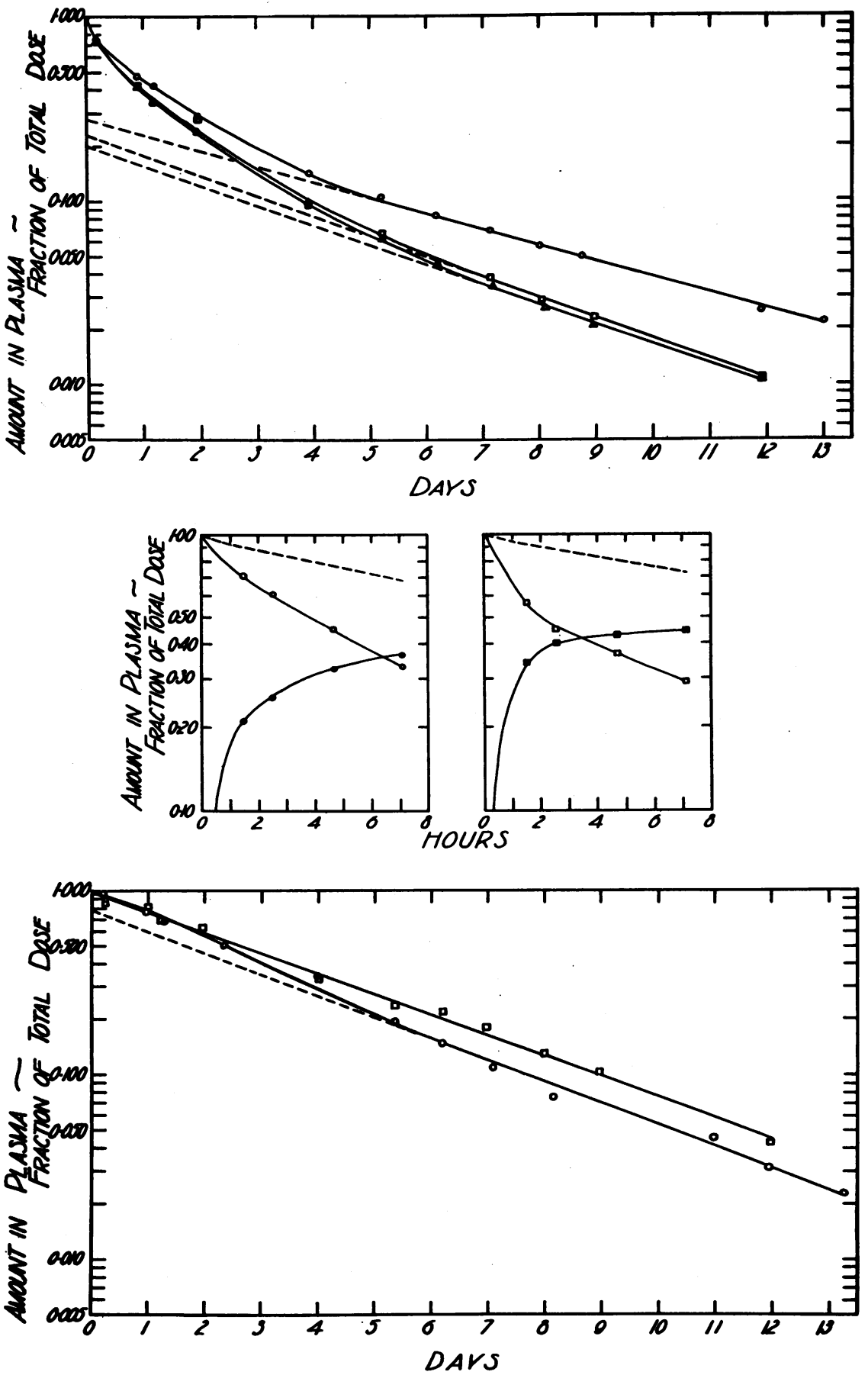

Fig. 3. The Disappearance of Radioactivity from the Circulation After Intravenous InJection of Iodinated "Normal" Low Density Lipoproteins Upper chart, total plasma radioactivity in normal adults: $\square$ J. B. $\triangle$ R. B. OE.S. Middle charts:

Total plasma radioactivity

Low density lipoproteins

$\mathrm{S}_{\mathrm{f}} 3$ to 9 lipoproteins

W. H. D. C.

$$
-\cdots \quad---
$$

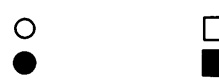

Lower chart, total plasma radioactivity in nephrotic children: O J. G. $\square$ D. O. 
used directly.for estimation of the volume of distribution of a body pool of endogenous protein, particularly in an edematous child. The volumes of distribution for endogenous plasma proteins determined by simple extrapolation of these curves would be overestimated to a degree reflected by: 1) the higher fractional rate of catabolism of labeled protein prior to establishment of the steady state (22), and 2) the higher specific activities of labeled protein present extravascularly compared to the specific activities in the plasma during the steady state (10). Estimation of the volume of distribution by the method of Berson, Yalow, Schreiber, and Post (22) tends to correct the plasma disappearance curves for the first factor, i.e., initial variations in the fractional rate of catabolism of labeled protein. Using the urinary excretion data and employing this method, the volumes of distribution of $S_{\mathbf{f}} 3$ to 9 lipoproteins in the two normal subjects, J. B. and E. S., and in the child in Group I, K. S., were, respectively, 2.22, 2.27 , and 2.17 times the plasma volumes; the plasma compartment contained 45 per cent, 44 per cent, and 46 per cent of the total body pool,
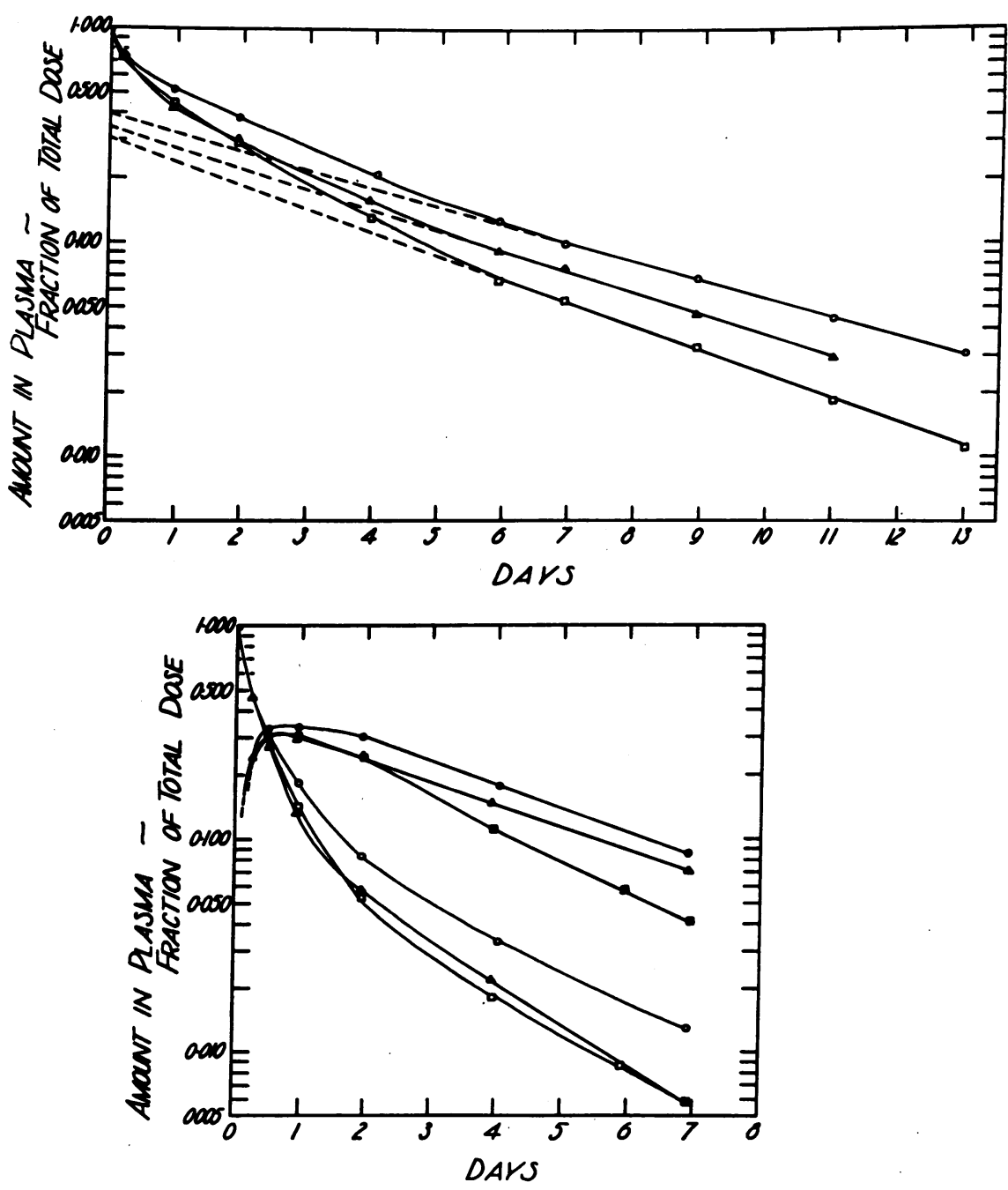

Fig. 4. The Disappearance of Radioactivity from the Circulation After INTRAVENOUS INJECTION OF IODINATEd "NEPHROTIC" LOW DENSITY LipoproteINS IN NORMAL ADULTS

Upper chart, total plasma radioactivity: $\triangle$ R. B. $\square$ E.P. OF.R.

Lower chart: open symbols indicate low density lipoproteins and solid symbols indicate lipoproteins of $S_{f} 3$ to 9 in same subjects as upper chart. 


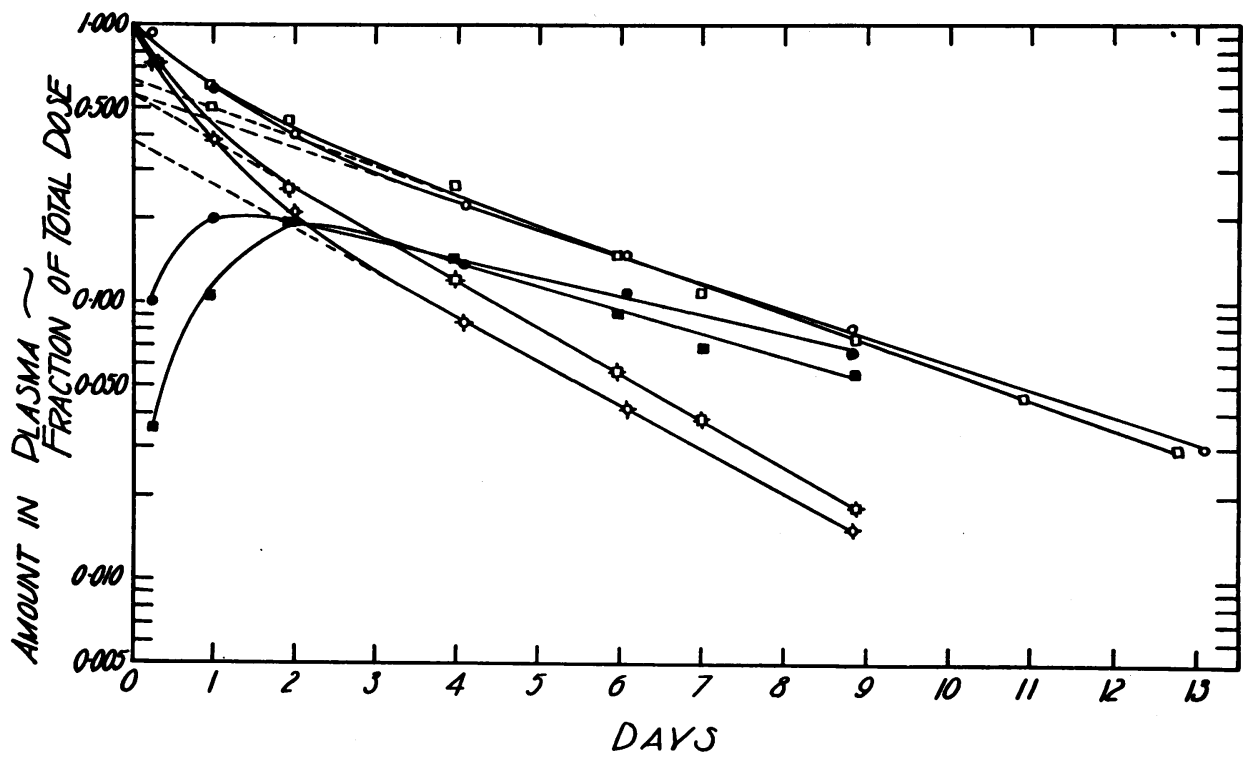

Fig. 5. The Disappearance of Total Radioactivity (Open Symbols), Low Density Lipoproteins (Starred Symbols) and $S_{f} 3$ to 9 Lipoproteins (Solid Symbols) from the Circulation After Intravenous injection of Iodinated "Nephrotic" Low DenSITY LIPOPROTEINS IN Two NePHROTIC ChILDREN

O J.G. $\square$ D. O.

respectively. Where there are marked differences in the specific activity of the labeled protein in different body compartments, however, or where there is significant retention of the labeled degradation products, this method cannot be used (10). Thus, the calculated volumes of distribution for $S_{f}$ 3 to 9 lipoproteins in the nephrotic children of Group III were larger than was indicated by direct analyses of edema and ascitic fluids; the concentration of $S_{f} 3$ to 9 lipoproteins in edema and ascitic fluids of these children, estimated by ultracentrifugal fractionation and cholesterol determinations, was found to be approximately 0.01 times that in the plasma. The specific activity of the iodinated $\mathrm{S}_{\mathrm{f}} 3$ to 9 lipoproteins in edema and ascitic fluids was found to be approximately three times that in the plasma after the steady state was established.

In Table II, A, are shown the calculated fractional rates of turnover as well as the turnover half-times obtained from them in the usual manner. It can be shown that, in the steady state,

$$
\mathrm{L}_{\mathrm{f}}^{*}=\frac{\lambda_{\mathrm{e}}}{\lambda_{\mathrm{t}}}
$$

where $L_{f} *$ is that fraction of the total dose of iodinated lipoprotein lost in the urine as labeled pro- tein, $\lambda_{\mathrm{e}}$ is the fraction of the body pool lost in the urine per unit time and $\lambda_{t}$ is the total fraction of the body pool replaced per unit time; $\lambda_{t}$ was obtained from the plasma disappearance curves. The fraction of the body pool catabolized per unit time, $\lambda_{c}$, was obtained from

$$
\lambda_{\mathrm{o}}=\lambda_{\mathrm{t}}-\lambda_{\mathrm{e}}
$$

III. Studies with radioiodinated serum lipoproteins of low density ( $S_{f}$ values of 10 to 200)

Lipoproteins of $S_{f} 10$ to 100 , isolated from sera of normal adults and labeled with radioiodine, were given to five normal adults and two nephrotic children of Group III. The disappearance of radioactivity from the plasma of these individuals is shown in Figure 3. Upon ultracentrifugal fractionation of individual sera at various times during the study, it was apparent that the radioactivity originally associated with lipoproteins of class $S_{t}$ 10 to 100 became increasingly associated with lipoproteins of class $S_{\mathbf{t}} 3$ to 9 as time progressed. Unfortunately, only random sera of these individuals were fractionated, except for two normal adults shown in Figure 3.

The overall behavior of lipoproteins of class $S_{\boldsymbol{t}}$ 10 to 200 obtained from a nephrotic child and la- 
beled with radioiodine was similar to, but not identical with, that of the labeled "normal" lipoproteins of $S_{f} 10$ to 100 . The labeled "nephrotic" low density lipoproteins were given to three normal adults and the same two children of Group III. The disappearance of total radioactivity from the plasma of these subjects and the relative amount of radioactivity in the different lipoprotein fractions were determined; the results are indicated in Figures 4 and 5. The initial, rapidly falling portion of the plasma disappearance curves for the low density lipoproteins was attributable to at least three factors: 1) diffusion from the vascular compartment, 2) conversion to higher density $\beta$-lipoproteins, and 3 ) catabolism. Later, the phase of steady logarithmic decline was presumably mainly due to the last two factors. In the nephrotic children, less than 3 per cent of the total dose was lost in the urine as lipoproteins, but the classes of lipoproteins that this represented could not be determined. It will be noted that the conversion of low density lipoproteins to $S_{\mathrm{f}} 3$ to 9 lipoproteins was decreased in the nephrotic children compared to the normal adults; in the normal adults, labeled $S_{f} 3$ to 9 lipoproteins appeared more rapidly and reached a higher level than in the nephrotic children.

The volume of distribution of the low density lipoproteins could not be accurately determined from the plasma disappearance curves. In addition to the factors mentioned in the case of the lipoproteins of $S_{f} 3$ to 9 , there was the additional complication of a rapid conversion of low density lipoproteins to those of $S_{f} 3$ to 9 in the normal adults. The situation in the normal subjects was analogous to that described for albumin in nephrotic children (10) where an equally rapid loss to the vascular pool of a specific protein occurred through urinary loss instead of by conversion. It was reported that under these circumstances the estimated volumes of distribution were severalfold too large and the estimated half-times of turnover were too long.

\section{Studies with radioiodinated $\alpha$-lipoproteins}

Radioiodinated normal $\alpha$-lipoproteins were given to two normal adults and three children with the nephrotic syndrome (Table II, B). The disappearance of these lipoproteins from the plasma of these individuals is shown in Figure 6. Ultra-

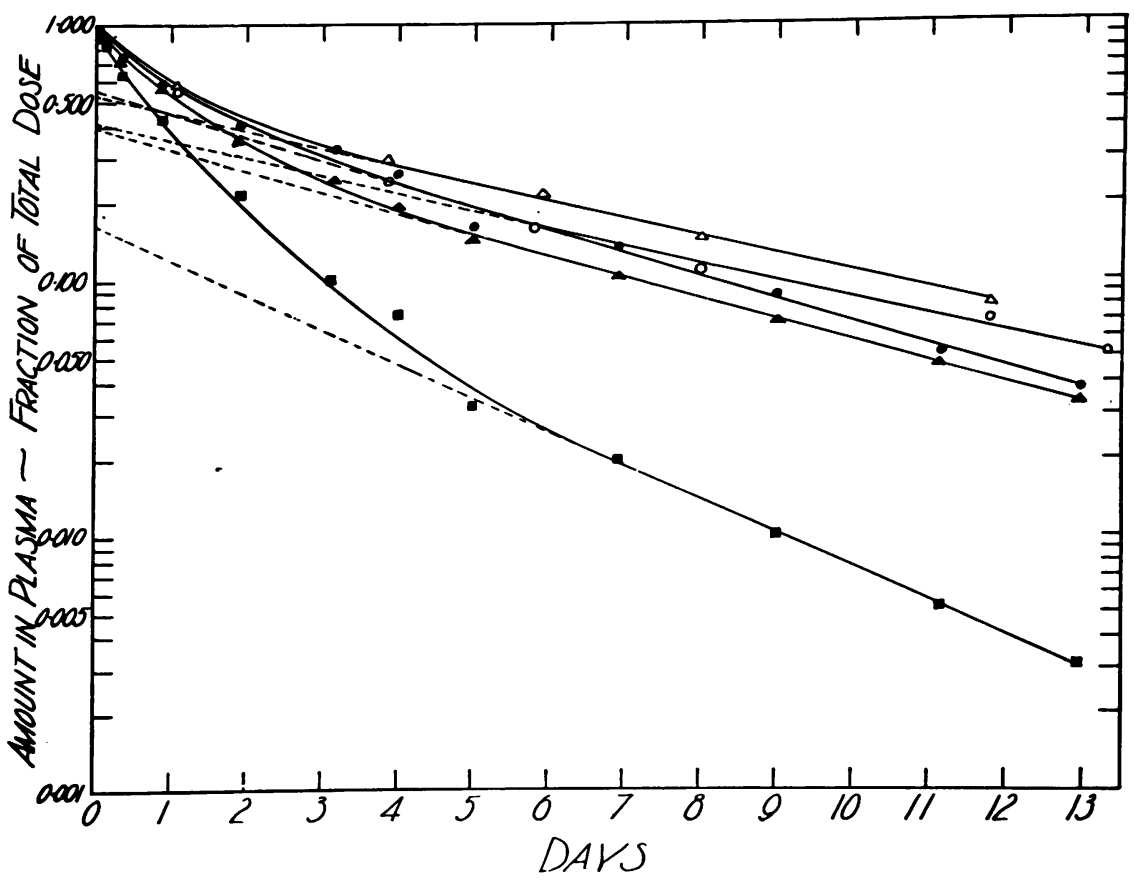

Fig. 6. The Disappearance of IODINATEd $\alpha$-Lipoproteins From the Circulation After Intravenous Injection

$\triangle$ J.K. OB.S. K.S. $\triangle$ E. T. D.W. 
centrifugal fractionation of the sera did not reveal any significant shift of radioactivity to chylomicra or to any of the other lipoprotein fractions.

The two normal adults revealed no detectable iodinated lipoprotein in the urine; the child of Group I lost only 1 per cent of the total dose in the urine as protein. The volumes of distribution of $\alpha$-lipoproteins in these three persons averaged 2.0 times the plasma volume when calculated according to the method of Berson, Yalow, Schreiber, and Post (22). The two children of Groups II and III, E. T. and D. W., excreted, respectively, 19 and 25 per cent of the total dose of labeled $\alpha$-lipoproteins in the urine as labeled protein. The turnover of $\alpha$-lipoproteins in these patients as calculated from equations 1 ) and 2) is shown in Table II, B. In the case of D. W., where a relatively large urinary loss of labeled protein occurred in a child with anasarca and ascites, the turnover half-time as estimated from the plasma disappearance curve represents a maximum value (10); therefore, the derived turnover half-time due to catabolism also represents a maximum value.

\section{DISCUSSION}

It is apparent that the metabolism of the $\alpha$-lipoproteins differs from that of the $\beta$-lipoproteins. After intravenous injection of $\alpha$-lipoproteins labeled in the peptide moiety with radioiodine, significant radioactivity was not detected in chylomicra or in lipoproteins of lower density or of slower mobility. Similarly, radioactivity originally injected in association with the peptide moiety of the labeled $\beta$-lipoproteins was not found subsequently in $\alpha$-lipoproteins or in chylomicra. In contrast, the labeled peptide moiety of low density $\beta$-lipoproteins rapidly appeared in $\beta$-lipoproteins of higher density soon after intravenous injection, but the labeled peptide of high density $\beta$-lipoproteins could not be detected in significant amounts in the low density lipoproteins even after several weeks in vivo. The evidence does not seem to support the suggestion of Korn that the peptide moieties of $\alpha$-lipoproteins, $\beta$-lipoproteins and chylomicra are intimately related, entering into a common metabolic cycle for the transfer of lipids (9). Instead, the findings suggest that, in humans at least, the metabolism of the peptide moiety of $\alpha$-lipoprotein is independent of the me- tabolism of the peptide moiety of $\beta$-lipoprotein and that there is no direct conversion of $\alpha$ - or $\beta$-lipoprotein in the formation of chylomicra. It is not possible to determine from our data whether the peptide portion of chylomicra ever becomes that of either the $\alpha$ - or $\beta$-lipoproteins, or if it does occur, whether such conversion is quantitatively significant.

This concept of lipoprotein metabolism is in accord with immunochemical studies of the lipoproteins. Although the $\beta$-lipoproteins are heterogeneous as regards quantitative precipitation with specific antisera, the haptenic groups of the peptide moieties of the $\beta$-lipoproteins studied are at least qualitatively similar irrespective of the density of the $\beta$-lipoprotein molecule (23-25). Moreover, antisera against $\beta$-lipoproteins do not react with $\alpha$-lipoproteins.

The metabolism of $\alpha$-lipoproteins in the nephrotic syndrome is similar to that found for other plasma proteins such as albumin or $\gamma$-globulin (10); in the full-blown disease, the fractional rate of catabolism of $\alpha$-lipoproteins is increased.

In the children reported here, hypercholesterolemia was due to an elevation of the plasma concentration of low density lipoproteins. This is in accord with the observations of Havel, Eder, and Bragdon (3) in nephrotic adults. It would appear from the data that this finding is associated with a decrease in the conversion of the low density lipoproteins to lipoproteins of $\mathrm{S}_{\mathrm{f}} 3$ to 9 . This decrease in conversion could be attributed to either: 1) an increase in plasma concentration of low density lipoproteins with saturation of a normal conversion system, or 2) a decrease in one or more factors essential to the conversion process. The second possibility is compatible with the observation that albumin is necessary for the binding of fatty acids liberated by the hydrolysis of neutral fats by lipoprotein lipase (26); an absence of albumin or a deficiency of lipoprotein lipase in the system results in decreased hydrolysis. The possible relationship between hyperlipemia and hypoalbuminemia has been studied by a number of investigators (27-30). It has been reported that repeated infusions of concentrated albumin in patients with the nephrotic syndrome resulted in a fall in plasma cholesterol (30) and, similarly, that albumin infusions in nephrotic rats reduced cholesterol and total lipids (27). 
It has also been observed, however, that children with the nephrotic syndrome show varying degrees of lipoprotein lipase deficiency (31) ; Rosenman and Friedman have recently reported similar findings in nephrotic rats (32). It has been found that in some nephrotic children, hypercholesterolemia was due primarily to an elevation of lipoproteins of $S_{f} 3$ to 9 , but, in these instances, the $\mathrm{S}_{\mathrm{f}} 10$ to 200 lipoproteins were also elevated (33, 34).

It has been implicitly assumed in this study that the iodinated lipoproteins behaved metabolically as did the native proteins. However, some of the results obtained are not readily explained. Careful examination of the middle graph of Figure 3 suggests some heterogeneity in the labeled low density lipoproteins with respect to conversion; whether this was the result of partial denaturation due to iodination or an inherent heterogeneity in the conversion rates of low density lipoproteins could not be determined. It will also be noted that the initial plasma disappearance of total radioactivity from iodinated "normal" low density lipoproteins in the nephrotic children (bottom graph, Figure 3) appeared to be slower than that obtained with analogous "nephrotic" lipoproteins in the same children (Figure 5). It is not known whether this was due to an actual difference in the native lipoproteins, a difference in the state of the children, or a difference induced by iodination.

\section{SUM MARY}

Ultracentrifugal fractionation of sera from six normal adults and six children in various phases of the nephrotic syndrome revealed that hypercholesterolemia and hyperlipemia in the nephrotic syndrome are associated with an elevation of low density lipoproteins, those of $S_{\mathrm{f}} 10$ to 200 . Serum concentrations of lipoproteins of $S_{f} 3$ to 9 and of $\alpha$-lipoproteins were relatively normal or somewhat decreased in the nephrotic children studied.

The peptide moieties of $\alpha$-lipoproteins, lipoproteins of $S_{\mathbf{f}} 3$ to 9 and lipoproteins of $S_{\mathbf{f}} 10$ to 100 from normal adults and of $S_{f} 10$ to 200 lipoproteins from a nephrotic child were labeled with $\mathrm{I}^{131}$. Tracer doses of these iodolipoproteins were given intravenously to children with the nephrotic syndrome and to normal individuals. The disappearance of specific radioiodinated protein from the plasma and the appearance of radioactivity in other plasma protein fractions and in the urine were investigated.

It was found that the fractional rate of catabolism of $\alpha$-lipoprotein was somewhat increased in a nephrotic child with anasarca and ascites. In two nephrotic children, 19 per cent and 25 per cent, respectively, of the tracer dose of radioiodinated $\alpha$-lipoproteins were excreted in the urine as labeled protein.

The fractional rate of catabolism of $S_{\mathrm{f}} 3$ to 9 lipoproteins tended to be somewhat increased in the nephrotic patients. Less than 3 per cent of the total dose of $S_{\mathrm{f}} 3$ to 9 iodolipoproteins appeared in the urine as labeled protein in those children with significant proteinuria.

The metabolism of the low density lipoproteins was complex. In both normal and nephrotic persons, a significant proportion of the $S_{\mathrm{f}} 10$ to 200 iodolipoproteins was converted to those of $S_{f} 3$ to 9. In the nephrotic children, the conversion of low density lipoproteins was decreased.

\section{REFERENCES}

1. Oncley, J. L. Lipoproteins of human plasma. Harvey Lect. 1954-1955, 50, 71.

2. Kunkel, H. G., and Trautman, R. The $\alpha_{2}$ lipoproteins of human serum. Correlation of ultracentrifugal and electrophoretic properties. J. clin. Invest. 1956, 35,641 .

3. Havel, R. J., Eder, H. A., and Bragdon, J. H. The distribution and chemical composition of ultracentrifugally separated lipoproteins in human serum. J. clin. Invest. 1955, 34, 1345.

4. Lindgren, F. T., Nichols, A. V., and Freeman, N. K. Physical and chemical composition studies on the lipoproteins of fasting and heparinized human sera. J. phys. Chem. 1955, 59, 930.

5. Oncley, J. L., and Mannick, V. G. Studies on the human plasma lipoproteins. Trans. Fifth int. Congr. on Blood Transfusion, Paris 1954, p. 116.

6. Oncley, J. L., Walton, K. W., and Cornwell, D. G. A rapid method for the bulk isolation of $\beta$-lipoproteins from human plasma. J. Amer. chem. Soc. In press.

7. Gould, R. G. Lipid metabolism and atherosclerosis. Amer. J. Med. 1951, 11, 209.

8. Kunkel, H. G., and Bearn, A. G. Phospholipid studies of different serum lipoproteins employing P-32. Proc. Soc. exp. Biol. (N. Y.) 1954, 86, 887.

9. Korn, E. D. Clearing factor, a heparin-activated lipoprotein lipase. II. Substrate specificity and activation of coconut oil. J. biol. Chem. 1955, 215, 15.

10. Gitlin, D., Janeway, C. A., and Farr, L. E. Studies on the metabolism of plasma proteins in the ne- 
phrotic syndrome. I. Albumin, $\gamma$-globulin and iron-binding globulin. J. clin. Invest. 1956, 35, 44.

11. Randolph, M. L., and Ryan, R. R. A slicer for sampling liquids. Science 1950, 112, 528.

12. de Lalla, O. F., and Gofman, J. W. Ultracentrifugal analysis of serum lipoproteins in Methods of Biochemical Analysis, D. Glick, Ed. New York, Interscience Publishers, 1954, vol. 1, p. 459.

13. Williams, J. W., Saunders, W. M., and Cicirelli, J. S. Size distribution analysis in plasma-extender systems. I. Gelatin. J. phys. Chem. 1954, 58, 774.

14. Cohn, E. J., Gurd, F. R. N., Surgenor, D. M., Barnes, B. A., Brown, R. K., Derouaux, G., Gillespie, J. M., Kahnt, F. W., Lever, W. F., Liu, C. H., Mittelman, D., Mouton, R. F., Schmid, K., and Uroma, E. A system for the separation of the components of human blood: Quantitative procedures for the separation of the protein components of human plasma. J. Amer. chem. Soc. 1950, 72, 465.

15. Hillyard, L. A., Entenman, C., Feinberg, H., and Chaikoff, I. L. Lipid and protein composition of four fractions accounting for total serum lipoproteins. J. biol. Chem. 1955, 214, 79.

16. Latta, H. Experimental hypersensitivity in the rabbit. Blood and tissue concentrations of foreign proteins labeled with radioactive iodine and injected intravenously. J. Immunol. 1951, 66, 635.

17. Pressman, D., and Eisen, H. N. The zone of localization of antibodies. V. An attempt to saturate antibody-binding sites in mouse kidney. J. Immunol. 1950, 64, 273.

18. Ray, B. R., Davisson, E. O., and Crespi, H. L. Experiments on the degradation of lipoproteins from serum. J. phys. Chem. 1954, 58, 841.

19. Yalow, R. S., and Berson, S. A. Chemical and biological alterations induced by irradiation of $\mathrm{I}^{131}$ labeled human serum albumin. J. clin. Invest. 1957, 36, 44.

20. Kunkel, H. G., and Slater, R. J. Zone electrophoresis in a starch supporting medium. Proc. Soc. exp. Biol. (N. Y.) 1952, 80, 42.

21. Abell, L. L., Levy, B. B., Brodie, B. B., and Kendall, F. E. A simplified method for the estimation of total cholesterol in serum and demonstration of its specificity. J. biol. Chem. 1952, 195, 357.
22. Berson, S. A., Yalow, R. S., Schreiber, S. S., and Post, J. Tracer experiments with $\mathrm{I}^{12 \mathrm{I}}$ labeled human serum albumin: Distribution and degradation studies. J. clin. Invest. 1953, 32, 746.

23. Gitlin, D. The immunochemical heterogeneity of human plasma $\beta$-lipoprotein. Science 1953, 117, 591.

24. Levine, L., Kauffman, D. L., and Brown, R. K. The antigenic similarity of human low density lipoproteins. J. exp. Med. 1955, 102, 105.

25. Aladjem, F., Lieberman, M., and Gofman, J. W. Immunochemical studies on human plasma lipoproteins. J. exp. Med. 1957, 105, 49.

26. Nikkilä, E. A., and Hashti, E. On the mechanism of the heparin-induced lipemia clearing reaction. Acta chem. scand. 1954, 8, 363.

27. Rosenman, R. H., Friedman, M., and Byers, S. O. The causal role of plasma albumin deficiency in experimental nephrotic hyperlipemia and hypercholesteremia. J. clin. Invest. 1956, 35, 522.

28. Thomas, E. M., Rosenblum, A. H., Lander, H. B., and Fisher, R. Relationships between blood lipid and blood protein levels in the nephrotic syndrome. Amer. J. Dis. Child. 1951, 81, 207.

29. Gurin, S. Discussion of paper by Langdon, R. G. Cholesterol metabolism in Fat Metabolism, Report of the Eleventh $M$ \& $R$ Pediatric Research Conference, Johns Hopkins Hospital. Columbus, M \& R Laboratories, 1954, p. 42.

30. Soothill, J. A., and Kark, R. M. The effects of infusion of salt-poor human serum albumin on serum cholesterol cholinesterase, and albumin levels in healthy subjects and in patients ill with the nephrotic syndrome. Clin. Res. Proc. 1956, 4, 140.

31. Gitlin, D., and Gross, P. A. M. The mechanism of hyperlipemia in the nephrotic syndrome. Trans. Soc. Pediat. Res. May, 1957.

32. Rosenman, R. H., and Friedman, M. In vivo studies of the role of albumin in endogenous and heparin-activated lipemia-clearing in nephrotic rats. J. clin. Invest. 1957, 36, 700.

33. Gitlin, D., Gross, P. A. M., and Numa, S. Unpublished data.

34. Baxter, J. H., Goodman, H. C., and Havel, R. J. Hyperlipemia of nephrosis (abstract). J. clin. Invest. 1957, 36, 873. 